\title{
LOYALITAS KONSUMEN : PERAN CITRA MEREK PASMIRA DI GRESIK
}

\author{
Anisa Herawaty ${ }^{1}$ \\ Universitas Muhammadiyah Gresik
}

\begin{abstract}
The purpose of this research is to find out the influence of brand image toward customer loyalty at pasmira Gresik. The population is customers who visited and purchased inpasmira outlet Gresik.Purposive sampling was used and 150 people have been selected as sample.Validity andreliability item measured by using modelling RASCH and the analysis technique has been done by using simple linier regression. The correlation test result showsr $=0,729, p=0,000(p<0,05)$; there is a positive relationship between the brand image with customer loyalty. The result of regression ( $t$ test) testing showed beta nol score $=-2.138(a)$ and $\left(b_{1}\right)$ score $=0,282$ regression line equations used Least Aquares Method $(y=a+b x), \quad y=-2,138+0,282 x$. Based on regression test result withdrawn conclusion Ha rejected and Ho accepted. There is no partial effect between variable of brand image to customer loyalty variable.
\end{abstract}

Keywords : Brand Image, Customer Loyalty

\begin{abstract}
Abstrak
Penelitian ini bertujuan untuk mengetahui pengaruh citra merek terhadap loyalitas konsumen pasmira Gresik. Populasi yang digunakan dalam penelitian ini adalah konsumen yang berkunjung dan membeli di outlet pasmira Gresik dengan teknik sampel yang digunakan adalah purposive sampling, dan jumlah sampel sebanyak 150 orang. Validitas dan reliabilitas item menggunakan pemodelan RASCH. Teknik analisis data menggunakan regresi linier sederhana. Hasil uji korelasi menunjukkan $r=0,729, p=$ $0,000(\mathrm{p}<0,05)$. Hal ini menunjukkan ada hubungan positif antara citra merek dengan loyalitas konsumen. Hasil uji regresi (uji t) menunjukkan nilai beta nol $=-2,138(\alpha)$ dan nilai $\left(b_{1}\right)=0,282$ maka persamaan garis regresi menggunakan Least Squares method (y $=\mathrm{a}+\mathrm{bx}), \mathrm{y}=-2,138+0,282 \mathrm{x}$. Berdasarkan hasil uji regresi ditarik kesimpulan Ha ditolak Ho diterima. Hal menunjukkan tidak terdapat pengaruh secara parsial antara variabel citra merek terhadap variabel loyalitas konsumen.
\end{abstract}

Kata Kunci : Citra Merek, Loyalitas Konsumen

\footnotetext{
${ }^{1}$ email : anisaherawati842@gmail.com

Prodi Psikologi Fakultas Psikologi

Jalan Sumatra No.101 Gresik Kota Baru (GKB) Gresik
} 


\section{Pendahuluan}

Era globalisasi saat ini memberikan tantangan tersendiri bagi pelaku bisnis, karena di era globalisasi ini banyak sekali produk yang membanjiri pasar. Perkembangan dunia bisnis yang demikian pesat membuat persaingan bisnis semakin meningkat, terlebih bagi produsen yang menghasilkan produk sejenis. Oleh karena itu dibutuhkan strategi yang mumpuni agar produk yang diciptakan mampu bersaing dan merebut pangsa pasar.Saat ini trend berbusana muslim sedang booming dikalangan masyarakat hal ini tentu memunculkan persaingan yang ketat bagi produsen busana muslim. Berbagai produk gamis dan hijab bermunculan di pasar fashion muslim, mengingat semakin pesatnya permintaan produk gamis dan hijab sehingga masing-masing produsen berlomba-lomba bersaing dan merebut pangsa pasar agar konsumen membeli produk tersebut.

Merek Rabbani, raja busana muslim dari Bandung.Dua puluh tahun lalu nama Rabbani memang tidak sekondang seperti sekarang. Jika dulu orang mengenal Rabbani sebagai salah satu toko buku islami kini nama yang memiliki arti "para pengabdi Allah yang mau mengajarkan dan diajarkan Kitab Allah" itu menjelma sebagai merek fashion muslim yang tersohor, khususnya produk jenis kerudung. Kerudung Rabbani dijual mulai dari Rp 20ribu- ratusan ribu dari kerudung balita hingga dewasa. Rabbani juga selalu menciptakan tren-tren kerudung. Kami menawarkan warna-warna ngejreng dan motif-motif beraneka ragam sehingga mampu mendobrak pakem-pakem desain dan motif yang ada kerudung rabbani menjadi market leader di Indonesia (tidak menyebutkan angka pasti-red). Sementara untuk posisi rabbani sendiri sebagai perusahaan adalah mengambil $10 \%$ dari keseluruhan pasar busana muslim di Indonesia (https://swa.co.id/ diakses tanggal 6 Desember 2017).

Untuk mengantisipasi persaingan pasar fashion muslim beberapa upaya upaya yang telah dilakukan pasmira untuk mempertahankan kesetiaan konsumen akan produk pasmira tahun 2017 diantaranya :

1. Pihak pemasaran pada saat akan meluncurkan produk baru melakukan penyebaran kuisioner agar perusahaan mendapatkan masukan tentang produkproduk yang diharapkan oleh konsumen.

2. Pemasaran melakukan berbagai promosi secara berkala dengan cara memberikan discount khusus pada hari - hari tertentu seperti jumat,sabtu dan minggu. Mengadakan promosi dengan memberikan discountpada hari besar nasional yang dilakukan secara continue sehingga dapat menarik minat konsumen untuk membeli produk.

3. Pemasaran telah melakukan inovasi dengan menggunakan media online dan membuka peluang dengan sistem reseller dan dropship untuk memperluas jaringan penjualan dimana sebelumnya Pasmira mengandalkan penjualan dengan menggunakan sistem kemitraan (agen). 
4. Memberikan pelatihan tentang langkah $3 \mathrm{~S}$ pelayanan konsumen pada karyawan (SPG) sesuai dengan SOP karyawan pasmira. Berikut Adalah Laporan Penjualan Pasmira Periode 2015 - 2017.

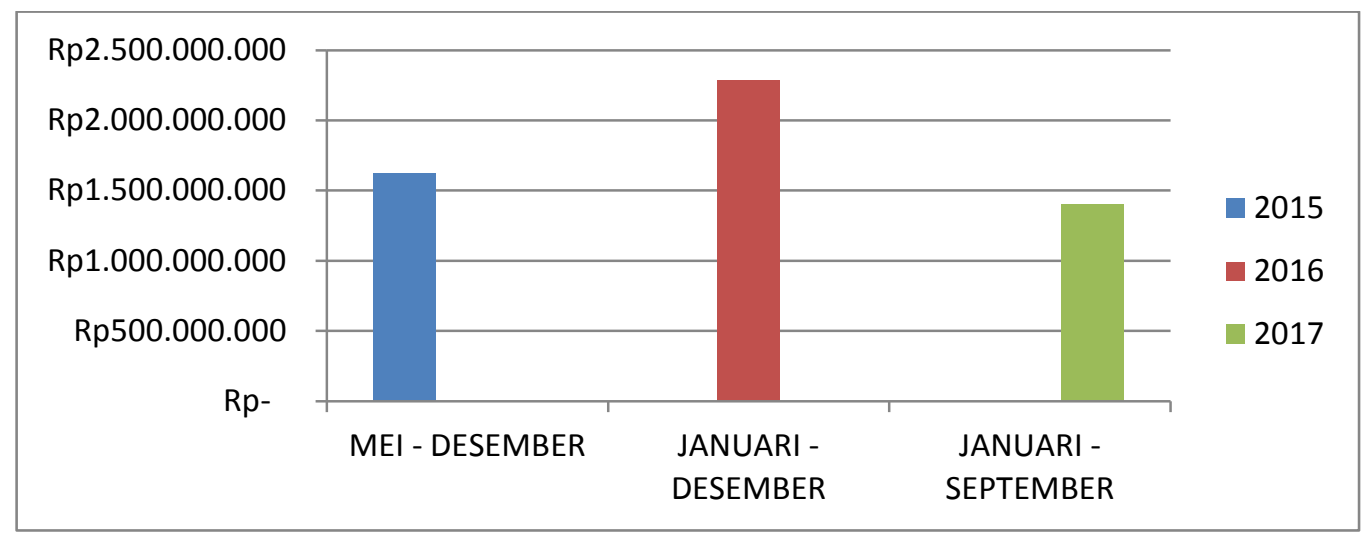

Sumber : Store Manager Pasmira Gresik

Gambar 1. Laporan Penjualan Pasmira Periode 2015 - 2017

Berdasarkan grafik penjualan diatas pada Mei hingga Desember 2015 nilai penjualan sebesar Rp. 1.624.892.672. Bila dibandingkan dengan tahun 2016 nilai penjualan pasmira mencapai Rp. 2.287.388.454 terdapat kenaikan nominal penjualan sebesar $0,71 \%$ sedangkan penjualan dibulan Januari hingga sepetember 2017 nilai penjualan sebesar Rp. 1.401.632.668. Jika dibandingkan dengan nilai penjualan pada bulan yang sama tahun 2016 terdapat penurunan penjualan produk sebesar $1,47 \%$.

Berdasarkan data diatas dapat dilihat penjualan produk pasmira pada tahun 2017 mengalami penurunan yang cukup signifikan. Hal ini berbanding terbalik dengan upaya-upaya yang telah dilakukan oleh pasmira untuk mempertahankan loyalitas konsumen terhadap produk yang dihasilkan. Seharusnya langkah yang dilakukan oleh pemasar dapat meningkatkan penjualan produk pasmira kenyataannya belum dapat tercapai dengan baik. Konsumen belum menunjukkan loyalitas terhadap produk fashion muslim pasmira.

Secara umum loyalitas konsumen diartikan sebagai kesetiaan seseorang atas suatu produk, baik barang maupun jasa tertentu. Loyalitas konsumen menggambarkan kelanjutan dari kepuasan konsumen dalam menggunakan produk barang atau jasa yang dihasilkan oleh perusahaan. Konsumen yang loyal akan senantiasa melakukan pembelian berkelanjutan terhadap barang atau jasa yang mereka gunakan sebelumnya (Griffin, 2005). 


\section{Tinjauan Pustaka}

\section{A. Loyalitas Konsumen}

Loyalitas secara harfiah diartikan kesetiaan, yaitu kesetiaan seseorang terhadap suatu objek. Kesetiaan konsumen sendiri melalui pembelian tidak terbentuk dalam waktu singkat namun melalui proses belajar dan berdasarkan hasil pengalaman konsumen itu dari pembelian konsisten sepanjang waktu. Loyalitas konsumen adalah kesetiaan konsumen untuk berbelanja suatu produk tertentu (Utami, 2006). Loyalitas konsumen adalah konsep multidimensi yang merupakan jenis preferensi pelanggan produk dan jasa yang terbentuk lama terkait dengan aspek kognitif, afektif dan konatif dari perilaku konsumen (Oliver, 1999 dalam Zhao Shijie \& Wang Lingfang, 2013:1-7). Konsumen yang loyal tetep berkomitmen melakukan pembelian pada merek yang sama, bersedia membayar dengan harga yang lebih tinggi untuk merek produk atau jasa dan selalu mempromosikan merek tersebut (Natarajan \& Sudha, 2016).

Mardalis (2005) menyatakan ada beberepa fakotor yang mempengaruhi loyalitas konsumen yaitu kepuasan pelanggan, kualitas jasa dan citra. Penelitian yang dilakukan Mangisi Hasibuan (2015) mengemukakan loyalitas dipengaruhioleh faktor nilai (harga dan kualitas), citra, kenyaman dan kemudahan, kepuasan ynag dirasakan konsumen, pelayanan dan garansi serta jaminan yang diberikan oleh merek.

Griffin (2005) mengemukakan karakteristik konsumen yang loyal yaitu :

1. Melakukan pembelian secara teratur.

Hal ini menunjukkan bahwa konsumen setia untuk melakukan pembelian berulang terhadap produk atau jasa tertentu dalam suatu periode tertentu.

2. Pembelian antarlini produk dan jasa.

Konsumen yang loyal tidak hanya membeli satu produk saja tetapi membeli lini suatu produk atau jasa lain pada satu badan usaha yang sama.

3. Mereferensikan pada orang lain.

Hal ini menunjukkan bahwa konsumen yang setia akan merekomendasikan hal-hal yang positif mengenai produk atau jasa dari perusahaan tertentu kepada rekan dan keluarga dan meykinkan bahwa produk atau jasa tersebut merupakan produk yang baik, sehingga orang lain akhirnya turut membeli dan menggunakan produk atau jasa tersebut.

4. Menunjukkan kekebalan terhadap pesaing.

Hal ini menunjukkan bahwa konsumen yang loyal akan menolak untuk mempertimbangkan tawaran produk atau jasa dari pesaing karena produk atau jasa yang dikonsumsinya telah memberikan kepuasan bagi konsumen.

\section{B. Citra Merek}

Merek (brand) adalah nama, istilah, tanda, simbol, rancangan, atau kombinasi dari semua untuk mengidentifikasi produk atau jasa dari satu merek dan membedakannya dari merek produk lain (Kotler \& Amstrong, 2008). Merek adalah produk atau jasa yang dimensinya mendiferensiasikan merek tersebut 
dengan beberapa cara dari produk atau jasa lainnya yang dirancang untuk memuaskan kebutuhan yang sama (Kottler dan Keller, 2009 : 249).

Citra sebagai jumlah dari gambaran-gambaran, kesan-kesan, dan keyakinankeyakinan yang dimiliki seseorang terhadap suatu objek (Kottlerdan Fox, 2002 dalam Sangadji dan Sopiah, 2013). Citra (image) dapat dideskripsikan dengan karakteristik-karakterisik tertentu seperti manusia, semakin positif deskripsi tersebut semakin kuat citra merekdan semakin banyak kesempatan bagi pertumbuhan merek (David, 2014).Citra terhadap merek berhubungan dengan sikap yang berupa keyakinan dan preferensi terhadap suatu merek. Citra adalah fungsi dari pengalaman dan juga harapan konsumen. Ketika konsumen membangun harapan dan realitas pengalaman dalam bentuk kualitas pelayanan teknis dan fungsional. Jika kualitas pelayanan yang dirasakan memenuhi citra atau melebihi citra, citra akan mendapat penguatan bahkan meningkat (Septian, 2016).Citra merek adalah persepsi terhadap merek yang tertanam pada benak konsumen dan mencerminkan keseluruhan kesan konsumen. Citra merek yang positif dapat dianggap sebagai kemampuan krusial perusahaan untuk mempertahankan posisinya dipasar(Chan $\mathrm{Wu}, 2011)$.

Schiffman dan Kanuk (2007) mendefinisikan persepsi sebagai proses psikologis dimana individu memilih,mengorganisasikan dan menginterprestasi stimuli menjadi sesuatu yang bermakna (dalam Tatik Suryani, 2013:75). proses persepsi diawali oleh stimuli yang mengenai indera konsumen. Stimuli yang merupakan segala sesuatu yang mengenai indera dan menimbulkan persepsi bisa bermacam-macam bentuknya, misalnya segala sesuatu yang dicium,segala sesuatu yang bisa dilihat, segala sesuatu yang bisa didengar dan segala sesuatu yang bisa diraba. Stimuli ini akan mengenai organ yang disebut sebagai sensory reseptor (organ manusia yang menerima input stimuli atau indera).Terjadinya stimulus yang mengenai sensory receptor mengakibatkan individu merespon. Respon langsung atau segera dari organ sensory receptor tersebut dinamakan sensasi. Tingkat kepekaan dalam sensasi anatara individu yang satu dengan yang lain berbeda-beda. Perbedaan sensitivitas antar individu tersebut terjadi karena kemampuan reseptor antar individu tidak sama. Selain sensitivitas faktor lain yag berpengaruh adalan intensitas dari stimuli. Stimuli yang mempunyai intensitas kuat akan memudahkan bagi resptor untuk menerimanya.

Faktor-faktor pembentuk citra merek menurut Keller (2013) terdiri dari tiga faktor yaitu kekuatan asosiasi merek, keunggulan asosiasi merekyang bergantung pada faktor desirability dan deliverability dan keunikan asosiasi merekyang bergantung pada faktor point of parity dan point of difference. Tiga dimensi citra merek menurut Keller (2013:76) yaitu : 
1. Atribut

Atribut adalah fitur - fitur yang mendeskripsikan suatu produk atau jasa dari merek yang bersangkutan. atribut terdiri atas product related attributes dan non product related attribute (atribut yang tidak berhubungan langsung dengan produk).

a. Product related attributes (atribut yang berhubungan langsung dengan produk).

Product related attributes didefinisikan sebagai bahanyang diperlukan agar fungsi produk atau jasa yang dicari konsumen dapat bekerja (Keller, 2013). Oleh karena itu product relatedattributes berhubungan dengan komposisi fisik produk atau kebutuhan layanan.

b. Non product related attributes(atribut yang tidak berhubungan langsung dengan produk).

Menurut Keller (2013 : 77) non product related attribute didefinisikan sebagai aspek eksternal dari produk atau jasa yang berhubungan dengan pembelian atau konsumsi. Atribut ini tercipta berkat proses bauran pemasaran dan bagaimana produk tersebut dipasarkan. Non product related attribute terdiri dari empat aspek yaitu informasi harga dan kemasan.

a) Informasi harga

Kottler (2009) harga adalah sejumlah uang yang dibebankan atas suatu produk atau jasa, atau jumlah dari nilai yang ditukar konsumen atas manfaat-manfaat karena memiliki atau menggunakan produk atau jasa tersebut.

b) Packaging (kemasan)

Keindahan pada kemasan merupakan daya tarik visual yang mencakup pertimbangan penggunaan warna, bentuk, merek, logo, ilustrasi, huruf, tata letak, dan maskot. Tujuannya untuk menarik konsumen secara visual dan dapat mengkomunikasikan suatu citra tertentu dari suatu merek.

2. Benefit (Manfaat)

Manfaat merupakan hasil positif yang diberikan atribut kepada konsumen. Menurut Keller (2013:77) benefit atau manfaat adalah nilai personal yang melekat pada atribut produk atau jasa dan apa saja yang dapat diberikan produk atau jasa tersebut pada konsumen. Dimensi manfaat terdiri atas tiga aspek yaitu manfaat fungsional, pengalaman dan manfaat simbolik.

a. Manfaat fungsional (functional)

Manfaat fungsional adalah keuntungan intrinsik dari pemakaian produk atau jasa, biasanya berkaitan dengan atribut akan produk yang dapat memenuhi kebutuhan dan keinginan konsumen (Keller,2013:77).Motivasi ini sering dijadikan konsumen sebagai otivasi dasar untuk menggunkan 
suatu produk atau jasa, misalnya untuk memenuhi kebutuhan fisiologis atau keselamatan (Maslow dalam Erna Ferrinadewi, 2008 : 153). Manfaat ini sering dianggap sebagai manfaat utama sebab secara langsung mampu memuaskan kebutuhan konsumen dan sifatnya nyata. Indikator ini dilihat dari khasiat utama objek.

b. Manfaat pengalaman (experiental)

Manfaat ini pengalaman berhubungan dengan apa yang dirasakan konsumen saat menggunakan produk atau jasa. Manfaat ini didesain untuk memenuhi kebutuhan pengalaman seperti sensory pleasure, variety, dan cognitive stimulation (Keller, 2013 : 77). Indikator yang digunakan berkaitan dengan pengalaman setelah produk atau jasa dari suatu merek digunakan.

c. Manfaat simbolik (symbolic)

Manfaat ini tidak berkaitan dengan produk melainkan berhubungan dengan kebutuhan mendasar untuk mengekspresikan diri dan bermasyarakat. Dengan manfaat simbolik ini konsumen dapat merasakan prestige, eksklusivitas dari sebuah merek karena terkait dengan kepribadian konsumen (Keller, 2013:78). Dari penjelasan tersebut dapat disimpulkan bahwa manfaat ini memberikan rasa bangga terhadap diri konsumen saat menggunakan produk tertentu sehingga memenuhi rasa bangga konsumen.

d. Brand attitude(sikap terhadap merek)

Brand attitude merupakan evaluasi keseluruhan konsumen atas suatu merek, apa yang dipercayai konsumen mengenai merek-merek tertentu, sejauh apa yang dipercaya konsumen atas produk atau jasa yang memiliki atribut atau keuntungan tertentu serta penilaian evaluatif terhadap kepercayaan tersebut. Sikap sering ditandai dengan keunggulan , kekuatan, dan keunikan. Keunggulan mengacu pada bagaimana produk memenuhi kebutuhan atau keinginan konsumen. Kekuatan (strength) mencerminkan sejauh mana citra merek masuk dan dipertahankan dibenak konsumen. Keunikan adalah seberapa banyak konsumen mengingat informasi yang berhubungan dengan merek tertentu (Keller, 1993 dalam Gordon et.al., 2016).

\section{Kerangka Konseptual}

Kerangka konseptual dalam penelitian ini adalah :

\begin{tabular}{|c|}
\hline Peran Citra Merk $\longrightarrow$ Loyalitas Konsumen \\
\hline
\end{tabular}

Gambar 2. Kerangka Konseptual 


\section{Metode Penelitian}

\section{Jenis Penelitian}

Penelitian ini merupakan penelitian kuantitatif deskriptif.Tipe penelitian yang digunakan adalah penelitian korelasi. Korelasi adalah cara untuk mengetahui ada tidaknya pengaruh antar variabel. Apabila terdapat pengaruh antar variabel, maka perubahan-perubahan yang terjadi pada salah satu variabel akan mengakibatkan terjadinya perubahan pada variabel lain (Susanti, 2010).

\section{Definisi Operasional Penelitian}

Definisi operasional adalah suatu definisi mengenai variabel yang dirumuskan berdasarkan karakteristik-karakteristik variabel tersebut yang diamati. Proses pengubahan definisi konseptual yang lebih menekankan kriteria hipotetik menjadi definisi operasional disebut operasionalisasi variabel peneliti (Azwar, $2007: 74)$.

Definisi operasional variabel penelitian yang digunakan adalah sebagai berikut:

1. Variabel terikat (Dependent Variable) :

Loyalitas konsumenadalah preferensi dan komitmen konsumen untuk melakukan pembelian ulangjilbab merek pasmira secara konsisten dari waktu ke waktu dan mereferensikannya pada orang lain.

Adapun indikator loyalitas konsumen yang digunakan pada penelitian ini mengacu pada Griffin (2005) adalah sebagai berikut:

a. Melakukan pembelian secara teratur.

b. Pembelian antarlini produk atau jasa.

c. Mereferensikan produk ke orang lain.

d. Menunjukkan kekebalan terhadap produk pesaing.

Pengukuran dari variabel penelitian ini menggunakan skala likert dengan interpretasi semakin tinggi skor maka akan semakin positif loyalitas bagi individu. Demikian juga sebaliknya semakin rendah skor maka akan semakin negatif loyalitas bagi individu.

2. Variabel bebas (Independent Variable):

Citra merekadalah keseluruhan persepsi konsumen terhadap merek yang terbentuk karena informasi dan pengalaman menggunakan jilbab merek pasmira.

1. Atribut

a. Product Related(berhubungan langsung dengan produk)

2. Non Product Related(tidak berhubungan langsung dengan produk)Manfaat

a. Manfaat fungsional

b. Manfaat pengalaman

c. Manfaat simbolis

3. Brand attitude (sikap terhadap merek)

Pengukuran variabel dalam penelitian ini menggunakan skala likert dengan interpretasi semakin tinggi skor maka akan semakin positif citra merek 
bagi individu, sebaliknya semakin rendah skor akan semakin negatif citra merek bagi individu.

\section{Populasi Dan Teknik Pengambilan Sampel}

Populasi adalah wilayah generalisasi yang terdiri atas obyek/subyek yang mempunyai kualitas dan karakteristik tertentu yang ditetapkan oleh peneliti untuk dipelajari dan kemudian ditarik kesimpulannya(Sugiyono, 2010 :80). Tehnik pengambilan sampel menggunakan teknik purposive Sampling.Populasi dari penelitian ini adalah konsumen yang berkunjung dan membeli dioutlet pasmira Gresik yang berjumlah 150 orang.

\section{Teknik Pengumpulan Data}

Metode pengumpulan data yang digunakan dalam penelitian ini adalah metode kuisioner atau angket. Metode kuisioner merupakan teknik pengumpulan data yang dilakukan dengan cara memberi seperangkat pertanyaan atau pernyataan tertulis kepada responden untuk dijawabnya (Sugiyono, 2010 : 142).Data penelitian ini diperoleh dengan menggunakan metode skala. Skala adalah skala adalah perangkat pertanyaan yang disusun untuk mengungkap atribut tertentu melalui respon terhadap pertanyaan yang diberikan (Azwar, 2012). Pada penelitian ini menggunakan skala model likert.

\section{Uji Validitas}

Validitas adalah seberapa jauh pengukuran oleh instrumen dapat mengukur atribut apa yang seharusnya diukur. Validitas dalam pengertian umum merupakan masalah interpretasi terhadap skor tes sesuai tujuan tes. Proses validasi melibatkan proses pengumpulan bukti untuk memberikan dasar ilmiah untuk interpretasi skor tes (Sumintono \& Widhiarso, 2015). Uji validitas dalam penelitian ini menggunakan validitas isi. Validitas isi merupakan validitas yang diestimasi melalui pengujian terhadap isi tes dengan analisis rasional atau melalui profesional judgement.

Perhitungan uji validitas dan reliabilitas menggunakan pemodelan $R A S C H$. Pemilihan item infit maupun outlier/misfit. Infit berarti inlier-sensitive atau information-weight fit adalah kesensitifan pola respons terhadap item sasaran pada responden atau sebaliknya. Outlier adalah pola jawaban yang tidak umum, misfit adalah inkonsistensi jawaban dari responden. Berdasarkan tiga kriteria pengukuran item pemodelan RASCH menurut (Boone et al, 2014 dalam Sumintono dan Wihiarso, 2015) yaitu :

Tabel 6. Tabel Kesesuaian Butir Item Measure RASCH

\begin{tabular}{lll}
\hline No. & Uraian & Kriteria \\
\hline 1. & Nilai outfit Mean Square (MNSQ) & $0,5<M N S Q<1,5$ \\
2. & Nilai outfit Z-Standard (ZSTD) & $-2,0<Z S T D<+2,0$ \\
3. & Nilai Point Measure Correlation (Pt Mean Corr) & $0,4<$ Pt Mean Corr $<0,85$ \\
\hline
\end{tabular}


Nilai outfit Mean-Square (MNSQ) memperlihatkan ukuran keacakan yaitu jumlah distori dalam sistem pengukuran. Nilai yang diharapkan adalah antara $0,5-$ 1,5.Jika skor kurang dari nilai tersebut, maka mengindikasikan soal itu terlalumudah ditebak (data overfit themodel).Nilai yang besar mengindikasikan tidak mudah diprediksi (data underfit the model). Secara statistik mean-square adalah nilai statistik chi-kuadrat yang dibagi dengan derajat bebas dan nilainya selalu positif.Sedangkan outfit berarti outlier-sensitive fit adalah mengukur kesensitifan pola respons item dengan kesulitan tertentu daripada responden (person) (Sumintono dan Widhiarso, 2015).

Tabel 7.Interpretasi Nilai Mean-square (MNSQ)

\begin{tabular}{cl}
\hline Nilai Mean-square $(M N S Q)$ & \multicolumn{1}{c}{ Implikasi pada pengukuran } \\
\hline$>2,0$ & Menurunkan kualitas sistem pengukuran \\
$1,5-2,0$ & Kurang bagus untuk pembuatan instrumen tapi tidak \\
& menurunkan kualitas \\
$0,5-1,5$ & Kondisi yang baik untuk pengukuran \\
$<0,5$ & Kurang produktif untuk pengukuran, namun tidak \\
& menurunkan kualitas, kemungkinan bisa menyebabkan \\
& kesalahan dengan reliabilitas yang tinggi. \\
\hline
\end{tabular}

Outfit Z-Standart (ZSTD ) adalah uji t untuk hipotesis, hasilnya adalah nilai$\mathrm{z}$ yaitu penyimpangan unit. Menjelaskan ketidakmungkinan data yaitu signifikansinya jika data memang sesuai dengan model (Sumintono dan Widhiarso, 2015).

Tabel 8. Interpretasi Outfit Z-Standart (ZSTD)

\begin{tabular}{cl}
\hline Nilai $Z S T D$ & Implikasi pada pengukuran \\
\hline$\geq 3,0$ & Data tidak diharapkan jika sesuai dengan model (secara \\
& sempurna). Namun dengan sampel yang besar kesesuaiannya \\
& mungkin kecil. \\
$2,0-2,9$ & Data tampak tidak dapt diprediksi \\
$-1,9-1,9$ & Data mempunyai perkiraan yang logis \\
$\leq 2,0$ & Data terlalu mudah diprediksi \\
\hline
\end{tabular}

Point Measure Correlation (Pt Mean Corr) pada prinsipnya sama dengan korelasi point-biserial dalam teori tes klasik. Parameter ini menunjukkan daya diskriminasi item (Sumintono dan Widhiarso, 2015).

Tabel 9. Interpretasi Point Measure Correlation (Pt Mean Corr)

\begin{tabular}{cl}
\hline Nilai Pt Mean Corr & \multicolumn{1}{c}{ Implikasi pada pengukuran } \\
\hline$>0,40$ & Sangat bagus \\
$0,30-0,39$ & Bagus \\
$0,20-0,29$ & Cukup \\
$0,00-0,19$ & Tidak mampu mendiskriminasi \\
$<0,00$ & Membutuhkan pemeriksaan terhadap butir \\
\hline
\end{tabular}


Nilai outfit MNSQ, outfit ZSTD dan Pt Mean Corr adalah kriteria yang digunakan untuk melihat tingkat kesesuaian butir (item fit). Item fit menjelaskan apakah butir soal berfungsi normal melakukan pengukuran atau tidak. Jika butir soal pada ketiga kriteria tersebut tidak terpenuhi dapat dipastikan bahwa item tersebut kurang sesuai (outlier / misfits). sehingga perlu diperbaiki atau dihilangkan (Boone et al, 2014 serta Bond \& Fox, 2015 dalam Sumintono dan Widhiarso, 2015).

\section{Uji Reliabilitas}

Reliabilitas mengacu pada konsistensi atau keterpercayaan hasil ukur yang mengandung makna kecermatan pengukuran (Azwar, 2014 : 29). Pengukuran yang tidak reliabel akan menghasilkan skor yang tidak dapat dipercaya karena perbedaan skor yang terjadi diantara individu lebih ditentukan oleh faktor error daripada faktor perbedaan yang sesungguhnya.

Uji reliabilitas dalam penelitian ini dianalisis dengan menggunakan pemodelan RASCH. Nilai reliabilitas dalam pemodelan RASCH ditunjukkan dengan nilai separasi individu (person separation), separasi individu menunjukkan seberapa baik seperangkat butir didalam tes menyebar sepanjang rentang atau kontinum kemampuan logit. Semakin besar skor separasi individu semakin baik tes yang disusun karena butir-butir didalamnya mampu menjangkau individu dengan kemampuan ditingkat tinggi sampai yang rendah. Separasi butir (item separation), separasi butir menunjukkan seberapa besar sampel yang dikenakan pengukuran tersebar sepanjang skala interval linier. Semakin tinggi nilai separasi butir semakin baik pengukuran yang dilakukan (Sumintono dan Widhiarso, 2015).

Nilai alpha cronbach, Azwar (2016) menjelaskan alfa cronbach adalah perhitungan melalui bentuk skala yang digunakan hanya satu kali maka problem yang mungkin timbul pada pendekatan reliabilitas tes ulang dapat dihindari. Kriteria nilai person reliability, item reliability dan nilai alpha cronbach pemodelan RASCH sebagai berikut :

Tabel 10. Kriteria Person Reliability, Item Reliability Dan Alpha Cronbach

\begin{tabular}{lll}
\hline No. $\quad$ Uraian & Kriteria \\
\hline 1. Nilai person reliability dan item reliability & a. $<0,67:$ Lemah \\
& b. $0,67-0,80$ Cukup \\
& c. $0,81-0,90$ Bagus \\
& d. $0,91-0,94$ Bagus sekali \\
2. Nilai alpha cronbach & e. $>0,94$ Istimewa \\
& a. $<0,5$ Buruk \\
& b. $0,5-0,6$ Jelek \\
& c. $0,6-0,7$ Cukup \\
& d. $0,7-0,8$ Bagus \\
& e. $>0,8$ Bagus sekali \\
\hline
\end{tabular}




\section{Hasil Penelitian Dan Pembahasan}

Dalam menganalisis data dalam penelitian ini adalah dengan menggunakan bantuan program SPSS ver. 18 for windows, dengan program analisis regresi linier sederhana.

Tabel 20. Hasil Uji Korelasi

\begin{tabular}{llrr}
\hline & & \multicolumn{2}{c}{ LoyalitasKons } \\
& & CitraMerek & umen \\
\hline CitraMerek & Pearson Correlation & 1 &, $729^{* *}$ \\
& Sig. (2-tailed) & &, 000 \\
& $\mathrm{~N}$ & 150 & 150 \\
LoyalitasKonsumen & Pearson Correlation &, $729^{* *}$ & 1 \\
& Sig. (2-tailed) &, 000 & \\
& $\mathrm{~N}$ & 150 & 150 \\
\hline
\end{tabular}

**. Correlation is significant at the 0.01 level (2-tailed).

Sumber : SPSS 18.00 for windows

Hasil analisis data korelasi product moment dari Pearson menunjukkan angka $\mathrm{r}_{\text {hitung }}=0,729, \mathrm{p}=0,000$ taraf signifikansi $\mathrm{p}<0,05$, dan $\mathrm{df}=\mathrm{n}-2=150-2=$ 148 dengan pengujian dua arah dapat diperoleh nilai $\mathrm{r}_{\text {tabel }}=0,160$ hasil tersebut menggambarkan bahwa $r_{\text {hitung }}>r_{\text {tabel }}(0,729>0,160)$. Sehingga dapat disimpulkan hipotesa nol (Ho) ditolak dan hipotesa alternatif (Ha) diterima yang artinya terdapat hubungan positif antara citra merek dengan loyalitas konsumen pada produk pasmira. Hal ini sejalan dengan penelitian yang menyatakanCitra berhubungan positif terhadap loyalitas pelanggan, sehingga semakin tinggi citra diharapkan memberikan dampak positif pada loyalitas konsumen (Sondoh, Omar et al, 2007). Image yang positif memberikan dampak yang positif dalam merebut hati konsumen bahkan menciptakan loyalitas konsumen terhadap produk (Saputri \& Pranata, 2014).

Tabel 21. Model Summary

Model Summary

\begin{tabular}{|c|c|c|c|c|}
\hline & $\mathrm{R}$ & R Square & $\begin{array}{l}\text { Adjusted R } \\
\text { Square }\end{array}$ & $\begin{array}{l}\text { Std. Error of } \\
\text { the Estimate }\end{array}$ \\
\hline 1 & $.729^{\mathrm{a}}$ & .532 & .528 & 5.494 \\
\hline
\end{tabular}

Hasil analisis data dari teknik regresi linear dari tabel model summary menunjukkan bahwa nilai $\mathrm{R}^{2}$ ( $R$ Square) sebesar 0,532 atau 53,2\%. Koefisian determinasi digunakan untuk mengetahui prosentase pengaruh variabel independen (predictor) terhadap perubahan variabel dependen. Dari tabel di atas dapat diartikan bahwa variabel independen (citra merek) mempengaruhi 
perubahan variabel dependen (loyalitas konsumen) adalah sebesar 53,2\% sedangkan sisanya $46,8 \%$ dipengaruhi oleh variabel lain selain variabel independen yang diteliti. Citra (image) yang kuat serta positif terhadap merek memberikan dampak yang signifikan dalam merebut hati konsumen bahkan menciptakan loyalitas konsumen terhadap produk tersebut (Syoalehat, Azizah dan Kusumastuti, 2012).

Tabel 23. Uji t

Coefficients $^{\mathrm{a}}$

\begin{tabular}{|c|c|c|c|c|c|c|}
\hline \multicolumn{2}{|c|}{ Model } & \multicolumn{5}{|c|}{ Standardized } \\
\hline & & Unstandardize & Coefficients & Coefficients & & \\
\hline & & $\mathrm{B}$ & Std. Error & Beta & $\mathrm{t}$ & Sig. \\
\hline \multirow[t]{2}{*}{1} & (Constant) & -2.138 & 4.719 & & -.453 & .651 \\
\hline & Citramerek & .282 & .022 & .729 & 12.958 & .000 \\
\hline
\end{tabular}

a. Dependent Variable: LoyalitasKonsumen

Uji t bertujuan untuk mengetahui pengaruh masing-masing atau secara parsial variabel independen (citra merek) terhadap variabel dependent (loyalitas konsumen). Dari tabel koefisien di atas nilai beta nol $-2.138(\alpha)$ dan nilai $\left(b_{1}\right)$ adalah 0,282 maka persamaan garis regresi menggunakan metode kuadrat terkecil (least aquares method) $\mathrm{y}=\mathrm{a}+\mathrm{bx}$ artinya Artinya $\mathrm{y}=-2.138+0,282 \mathrm{x}$ dari persamaan regresi di atas dapat diartikan koefisien regresi citra merek sebesar 0,282 menyatakan bahwa setiap penurunan 1 nilai citra merek, maka nilai loyalitas konsumen bertambah 0,282 .

Berdasarkan tabel dengan derajat kebebasan untuk taraf kesalahan 5\%, dengan $\mathrm{n}=150$ dan $\mathrm{k}$ (jumlah variabel independen) $=1$ diperoleh (df) $\mathrm{n}-\mathrm{k}-1=150$ $1-1=148$ maka $t_{\text {tabel }}=1,976$. Sehingga dapat disimpulkan bahwa tidak terdapat pengaruh secara parsial antara citra merekterhadap loyalitas konsumen pasmira.

\section{Kesimpulan Dan Saran}

\section{Kesimpulan}

Berdasarkan hasil analisa data penelitian, dapat ditarik kesimpulan bahwa $\mathrm{r}$ $=0,729, \mathrm{p}=0,000$ taraf signifikansi $\mathrm{p}<0,05$, dan $\mathrm{df}=\mathrm{n}-2=150-2=148$ dengan pengujian dua arah dapat diperoleh nilai $r$ tabel $=0,160$ hasil tersebut menggambarkan bahwa $r_{\text {hitung }}>r_{\text {tabel }}(0,729>0,160)$. Sehingga dapat disimpulkan hipotesa nol (Ho) ditolak dan hipotesa alternatif (Ha) diterima yang artinya terdapat "hubungan yang positif antara citra merek dengan loyalitas konsumen pada pasmira Gresik".

Hasil perhitungan regresi (uji t) menunjukkan nilai koefisien beta nol $2.138(\alpha)$ dan nilai $\left(b_{1}\right)$ adalah 0,282 dengan nilai $t_{\text {hitung }}=12.958$ maka persamaan garis regresi menggunakan metode kuadrat terkecil (least aquares method) yang 
didapat adalah $\mathrm{y}=\mathrm{a}+\mathrm{bX}$ artinya $\mathrm{y}=-2.138+0,282 \mathrm{x}$ sehingga persamaan regresi di atas dapat diartikan koefisien regresi citra merek sebesar 0,282 menyatakan bahwa setiap penurunan 1 nilai citra merek, maka nilai loyalitas konsumen bertambah 0,282. Berdasarkan hasil uji regresi diatas maka dapat disimpulkan Ha ditolak dan Ho diterima. Sehingga kesimpulannya bahwa tidak terdapat pengaruh secara parsial antara variabel citra merekterhadap variabel loyalitas konsumen.

\section{Saran}

\section{a. Bagi Perusahaan}

Produk fashion muslim merupakan salah satu produk industri kreatif. produk fashion muslim merupakan perpaduan antara soft skill dan nilai seni yang bergerak dinamis mengikut trend maka dibutuhkan inovasi-inovasi terkini untuk dapat menghasilkan produk yang sesuai dengan kebutuhan dan keinginan konsumen. Perusahaan jilbab pasmira hendaknya melakukan upaya perbaikan produk yang berkelanjutan dalam meningkatkan loyalitas konsumen. Upaya tersebut bisa berupa bekerjasama dengan designer fashion muslim untuk menciptakan produk jilbab yang up date dan mempunyai nilai jual yang tinggi sehingga mampu bersaing dengan kompetitor.

Pasmira hendaknya memantapkan konsep dari produk jilbab yang diusung menyesuaikan dengan kebutuhan dan keinginan konsumennya (apakah perlu melakukan konsep ulang atau merealisasikan citra pasmira dalam desain produk), serta mengevaluasi konsep tersebut secara continue. Selain itu pasmira hendaknya melakukan pemetaan riset konsumen tentang produk jilbabnya, riset tersebut dapat dilakukan saat sebelum dan setelah mengeluarkan produk jilbab yang baru. Pasmira hendaknya juga mengevaluasi semua yang berhubungan dengan produk melalui atribut. Salah satu yang harus diperhatikan atribut yang berhubungan langsung dengan produk (komposisi fisik produk berupa kualitas bahan, pemilihan desain, warna, kenyamanan). Atribut produk yang kurang baik dapat mempengaruhi konsumen untuk menggunakan merek dari produk. Produk yang mampu memenuhi kebutuhan dan keinginan konsumen akan membentuk image yang positif terhadap merek dari produk tersebut.

b. Bagi Penelitian Berikutnya

Bagi penelitian berikutnya diharapkan dapat lebih menyempurnakan lagi beberapa kelemahan dalam penelitian ini, kelemahan penelitian ini antara lain : perluasan populasi dan jumlah sampel serta keterbatasan dalam membuat dan mengolah instrumen agar hasil penelitian berikutnya dapat semakin baik lagi. Diharapkan untuk penelitian lain dapat lebih menggali lagi tentang loyalitas konsumen dan pengaruhnya dengan hal lain mengingat ada beberapa faktor yang mempengaruhi loyalitas selain citra merek seperti kualitas produk, desain, dan kepuasan konsumen. 


\section{Daftar Pustaka}

Azwar, S. (2007). Metode Penelitian. Yogyakarta: Pustaka Pelajar.

Azwar, S. (2012). Penyusunan Skala Psikologi. Yogyakarta: Pustaka Pelajar.

Azwar, S. (2014). Reliabiltas dan Validitas. Yogyakarta: Pustaka Pelajar.

Chan Wu, C. (2011). The Impact of Hospital Brand Image on Service Quality. Patient Satisfaction and Loyalty. African Journal of Business Management, 5(12), 4873-4882

Ferrinadewi, E. (2008). Merek Psikologi Konsumen. Yogyakarta: Graha Ilmu

Griffin, Jill. 2005. Customer Loyalty, Menumbuhkan dan Mempertahankan Kesetiaan Pelanggan. Jakarta : Erlangga.

Keller, K. L. (2013). Strategic Brand Management Building, Measuring, and Managing Brand Equity. Harlow, England: Pearson Education Limited.

Kotler, P., \& Amstrong, G. (2008). Principle of Marketing 14e. New Jersey: Pearson Prentice Hall.

Kotler, P., \& Keller, K. L. (2012). Marketing Management 14th edition. NewYork: Pearson Prentice Hall.

Kottler, P., \& Keller, K. L. (2009). Manajemen Pemasaran Edisi 13. Jakarta: Erlangga.

Mangisi Hasugian, T. J. (2015). Pengaruh Brand Image dan Brand Trust Terhadap Brand Loyalty Telkomsel. Jurnal Administrasi Bisnis, 3, 923-937.

Mardalis, A. (2005). Meraih Loyalitas Pelanggan. Benefit, 9, 111-119.

Natarajan, D., \& Sudha, V. (2016). A Relationship Between Brand Image and Brand Loyalty (A Sudy With Reference To FMCGConsumers In Vellore District). International Journal of Economic and Business Law, 4(5), 139145.

Sangadji, E. M., \& Sopiah. (2013). Perilaku Konsumen Pendekatan Praktis Disertai Himpunan Jurnal Penelitian. Yoyakarta: Andi.

Sondoh, S. L., Omar, M. W., \& et al. (2007). The Effect of Brand Image on Overall Satisfaction and Loyalty Intention in The Context of Color Cosmetic. Asian Academy of Management Journal, 12, 83-107. 
Shijie, Z., \& Lingfang, W. (2013). Improving Customer Loyalty By Getting Rid Of The Misunderstanding. Global Journal Of Management and Research Business Research Marketing, 13(10), 43-47.

Sumintono, B., \& Widhiarso, W. (2015). Aplikasi Pemodelan Rasch Pada Assesment Pendidikan. Cimahi, Trim Komunikata Publishing House.

Sugiyono. (2010). Metode Penelitian Kuantitatif Kualitatif dan $R \& D$. Bandung: CV Alfabeta.

Suryani, T. (2013). Perilaku Konsumen Di Era Internet. Yogyakarta: Graha Ilmu.

Susanti, M. N. (2010). Statistik Deskriptif Induktif. Yogyakarta: Graha Ilmu.

Syoalehat, Q. N., Azizah, S., \& Kusumastuti, A. E. (2012). Pengaruh Citra Merek (Brand Image) Terhadap Loyalitas Konsumen Bakso Bakar Pak Man Kota Malang. Jurnal Ilmu-ilmu Peternakan, 3, 20-26.

Utami, C. W. (2006). Manajemen Ritel Strategi dan Implementasi Ritel Modern. Jakarta: Salemba Empat.

https://swa.co.id/swa/trends/management/rabbani-raja-busana-muslim-daribandung. 